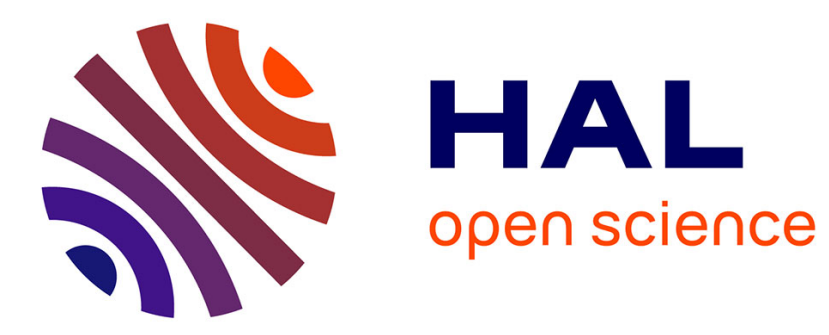

\title{
Was the Global Pact for the Environment a good idea?
} Sandrine Maljean-Dubois

\section{To cite this version:}

Sandrine Maljean-Dubois. Was the Global Pact for the Environment a good idea?. Yearbook of international disaster law, 2021, 2 (1), pp.283-313. 10.1163/26662531_00201_012 . halshs-03168874

\section{HAL Id: halshs-03168874 https://shs.hal.science/halshs-03168874}

Submitted on 25 Mar 2021

HAL is a multi-disciplinary open access archive for the deposit and dissemination of scientific research documents, whether they are published or not. The documents may come from teaching and research institutions in France or abroad, or from public or private research centers.
L'archive ouverte pluridisciplinaire HAL, est destinée au dépôt et à la diffusion de documents scientifiques de niveau recherche, publiés ou non, émanant des établissements d'enseignement et de recherche français ou étrangers, des laboratoires publics ou privés. 


\title{
Was the Global Pact for the Environment a good idea?
}

\author{
Sandrine Maljean-Dubois \\ [Yearbook of International Disaster Law, vol. 2, 2021, pp. 283-313]
}

For several decades, scientists have been raising the alarm about the threats human activities are posing to the environment. In these early years of the $21^{\text {st }}$ century, scientific publications and reports give us great cause for concern. In addition to climate change, which is already noticeable and acts as a threat multiplier for disasters, there is the looming prospect of a massive and abrupt collapse of biodiversity. And the consequences of human activities do not stop there. These activities are causing a global disruption to the way our biosphere works. Thus, scientists have identified nine 'planetary boundaries', like so many thresholds not to be exceeded at the risk of taking our biosphere out of a 'safe operating space'. ${ }^{1}$ The tipping point is thought to have already been crossed for at least four of these boundaries: biodiversity and climate change but also biogeochemical cycles of nitrogen and phosphorus as well as deforestation and land use change. ${ }^{2}$ The Earth is thought to have left the Holocene and entered, with the Industrial Revolution, a new geological era, the Anthropocene, marked by the significant impact of mankind on the Earth's ecosystem. This new term reflects a new reality, that of a human race that has become a geological force capable of leaving a permanent mark on its home planet, and of significantly disrupting the way it works, most likely in an irreversible manner. Since 1945, the Anthropocene has even seen a 'great acceleration'. ${ }^{3}$

States have put in place two international expert bodies whose recent reports, summarising current scientific knowledge, have confirmed the extreme gravity of the situation. The Intergovernmental Panel on Climate Change (IPCC), established in 1988, has confirmed the role of mankind in climate change. ${ }^{4}$ It warns of the consequences of an average temperature rise above $1.5^{\circ} \mathrm{C}$, while current emissions trajectories predict a rise of over $3^{\circ} \mathrm{C}$ before the end of this century, which would continue into the next century. ${ }^{5}$ In its first global assessment, the Intergovernmental science-policy platform for biodiversity and ecosystem services (IPBES), created in 2012, found that the demographic decline of many species heralds the collapse of biodiversity. Today, approximately one million plant and animal species are threatened with extinction, including in the coming decades, which is unprecedented in the history of mankind. ${ }^{6}$

The consequences are not just environmental or health-related, as the gravity of environmental threats also jeopardizes economic and social development. The latest report of the United Nations Environment Programme on the global environmental outlook, 'GEO 6', insists on the fact that:

'Without additional policies, trends in environmental degradation are projected to continue at a rapid rate and the related Sustainable Development Goal targets and internationally agreed environmental goals are not expected to be achieved, including on

\footnotetext{
${ }^{1}$ J. Rockström et al., 'A safe operating space for humanity', Nature (2009) Vol. 461 n²4, 473.

${ }^{2}$ W. Steffen et al., 'Planetary Boundaries: Guiding human development on a changing planet' Science (2015), Vol. $347 \mathrm{n}^{\circ} 6223,1259855$

${ }^{3}$ C. Bonneuil, J.-P. Fressoz, L'événement anthropocène, La terre, l'histoire et nous (Seuil 2016) 336.

${ }^{4}$ R.K. Pachauri, L.A. Meyer (eds), Climate Change 2014: Synthesis Report, Fifth Assessment Report (IPCC 2014) Geneva, 161 .

${ }^{5}$ V. Masson-Delmotte et al. (eds), Summary for policymakers, Global Warming of $1.5^{\circ} \mathrm{C}$, Special Report (IPCC 2018) 32.

${ }^{6}$ S. Diaz et al. (eds), Summary for policymakers of the global assessment report on biodiversity and ecosystem services of the Intergovernmental Science-Policy Platform on Biodiversity and Ecosystem Services (IPBES 2019) 39.
} 
climate change, biodiversity loss, water scarcity, excess nutrient run-off, land degradation and ocean acidification (...)' ${ }^{7}$

International environmental law has considerably expanded in the past fifty years. First a precious tool for States' cooperation, international law has also played an important role in the development of national environmental laws. However, when comparing these impressive legal developments with the quick worsening of the environmental issues regularly described in reports on the environment, it is clear that the abundance of rules has not produced the desired effect. International law has turned out to be unable to halt the current crisis.

Convinced that an international treaty setting out a number of fundamental principles of environmental protection could fill the gaps and strengthen the effectiveness of international environmental law, a group of French legal experts started working on a 'Global Pact for the Environment'. A number of senior authorities in France were convinced by the draft Pact and it was promoted internationally by French diplomacy. Although it gave rise to interesting discussions under the auspices of the United Nations, it did not receive sufficient support for actual negotiations to be launched. Despite the drafters' caution, which was guided by their concern for realism, the project seems to have been well and truly shelved, at least for the near and medium-term future, if not for longer. Following the chronology of this project, we will go over the background history of the project (part 1), before analysing its design (part 2) and recalling the process of its life and... death (part 3).

\section{Genesis of the Global Pact for the Environment}

There have been, in recent history, several proposals for a new environmental treaty that would be universal in scope and general in content. Indeed, at the international level, some general and universal instruments do exist, however, none of them are legally binding. Some of the most important ones include the Declaration on the Human Environment adopted at the Stockholm Conference in $1972,{ }^{8}$ the World Charter for Nature adopted by the UN General Assembly in 1982, ${ }^{9}$ and the Rio Declaration adopted at the Conference on the Environment and Development in $1992 .{ }^{10}$ These three instruments gave States an opportunity to define shared international frames of reference; each one of them, at the time it was adopted, reflected a consensus around a number of general principles.

Because environmental law is a rich and scattered area of law, which has developed, at various levels (bilateral, regional, universal), somewhat chaotically and often in a hurry to address needs as they were identified, general principles play a major role. They have greatly influenced the development of international environmental law, but also of domestic environmental laws. This is especially true of the Rio Declaration, thanks to its short length and normative statements. General principles facilitate harmonisation and establish a common thread in the vast web of instruments. They provide guidance in the interpretation of positive law, but also influence the practice of States and guide the negotiation of treaty rules and of decisions by Conferences of the Parties (COPs). They have spread into national laws that have often given them legislative, sometimes customary, status. Some principles have been clearly recognised as customary principles at the international level (prevention, impact assessment, compensation for transboundary harm). ${ }^{11}$ For others, included solely in non-legally binding

\footnotetext{
${ }^{7}$ UNEP, GEO 6, Summary for policymakers (UNEP 2019) 21.

${ }^{8}$ Stockholm Declaration, Report of the United Nations Conference on the Human Environment, Stockholm 5-16 June 1972, A/CONF.48/14/Rev/1, p. 3.

${ }^{9}$ United Nations General Assembly, Resolution A/RES/37/7 of 28 October 1982, World Charter for Nature.

${ }^{10}$ Rio Declaration, Report of the United Nations Conference on the environment and development, Rio de Janeiro, 314 June 1992, A/CONF.151/26, vol. 1, p. 3.

${ }^{11}$ See in particular Legality of the Threat or Use of Nuclear Weapons, Advisory Opinion, I.C.J. Reports 1996, p. 241, $\$ 27 ;$ Pulp Mills on the River Uruguay (Argentina v. Uruguay), Judgment, I.C.J. Reports 2010, p. 14; Certain Activities Carried Out by Nicaragua in the Border Area (Costa Rica v. Nicaragua) and Construction of a Road in Costa Rica along the San Juan River (Nicaragua v. Costa Rica), Judgment, I.C.J. Reports 2015, p. 665.
} 
instruments or in certain universal and/or regional conventions, their customary nature is still in debate. As international judicial decisions are rare, it is difficult to say where these principles stand in the process of customary crystallisation (precautionary principle, polluter-pays, environmental democracy, right to a healthy environment). ${ }^{12}$

The key idea underlying the project for a Global Pact for the environment was that major soft-law instruments would now benefit from being translated into a treaty. But the codification exercise could also be usefully supplemented by a gradual development of the principles of international environmental law. States could seize this opportunity to include in this 'global environmental constitution' some new principles that have emerged since the Rio Declaration, either as doctrinal proposals (the concept of planetary boundaries) or in domestic and/or international instruments but in a one-off and limited way, for a particular sector or region of the globe (resilience, non-regression, protection of environmental activists and whistle-blowers for example, acknowledgement of the role of non-State actors, protection of traditional knowledge...).

For its promoters, the launch of international negotiations towards a Pact for the environment was to open a useful conversation in order to, ultimately, clarify and consolidate the various principles by specifying their respective meaning, scope and significance. Setting them out in a new consolidated instrument would reduce uncertainties and render such principles more foreseeable, accessible and legible, for States and for other actors of international life. This new instrument was to provide a new basis for the harmonisation of national legislations, possibly even of national constitutions. As a sort of 'metanorm', it would combine the various conventional regimes into one single text that would be the cornerstone of international environmental law. These regimes being fragmented despite the constant interaction of elements of the environment, the Global Pact would create an indispensable link between them and improve their coherence. Lastly, by clarifying, consolidating and modernising principles of international environmental law, the Pact would facilitate their invocation before international or national courts. By promoting a right to a "ecologically sound environment" and principles of environmental democracy (access to information, public participation, access to justice), it would help reinforce the role of non-State actors at the national and international levels. Thanks to the broad and general nature of such a treaty, convention-based institutions that could be created pursuant thereto could play a major role in the implementation of international environmental law far beyond the treaty itself, thus producing positive impacts on sector-based regimes.

From this point of view, the Global Pact project was not an entirely novel idea, as it followed in the footsteps of a previous project, adopted in 1995 by the International Union for Conservation of Nature (IUCN), a very active non-governmental organisation that initiated several international conventions. ${ }^{13}$ The IUCN had observed that:

Most international agreements are sector specific in nature, concluded at different times at uneven stages of international knowledge and concern. They also vary regionally, so that norms applicable to some parts of the world do not apply elsewhere, or are global in scope but not yet universally ratified. ${ }^{14}$

This was why, three years after the adoption of the Rio Declaration, the World Commission on Environmental Law of the IUCN, in collaboration with the International Council of Environmental Law (ICEL), presented States with an extremely long and detailed

12 L. Boisson de Chazournes, S. Maljean-Dubois, 'Les principes du droit international de l'environnement', JurisClasseur Droit international $n^{\circ} 146-15$, JurisClasseur environnement $n^{\circ} 2010$ (Lexis-Nexis 2016).

${ }^{13} \mathrm{~J}$. Olivier, L'Union mondiale pour la nature (UICN) : Une organisation singulière au service du droit de l'environnement, (Bruylant 2005) 372. Some States are among the members of the IUCN, which makes it an original and hybrid organisation.

${ }^{14}$ See IUCN, Draft International Covenant on Environment and Development (IUCN 1995, $5^{\text {th }}$ edition) xxi $<$ https://portals.iucn.org/library/sites/library/files/documents/EPLP-031-rev4.pdf $>$ last accessed on 14 February 2020. 
'blueprint' for an international treaty. ${ }^{15}$ The IUCN was responding to the report by the Brundtland Commission that had recommended, in 1986, the drawing up of a universal declaration - that would become the Rio Declaration - and of an international treaty for environmental protection and sustainable development. ${ }^{16}$ Although it was amended and reissued several times in order to be presented at various international meetings and events, featuring after a while explanatory comments for each article, this draft Covenant on environment and development never convinced the States. ${ }^{17}$

Another project was published in 2017. It was an international covenant on environmental rights, shorter than the IUCN draft and centred around human rights. This time coming from a small group of French legal experts led by Michel Prieur, professor emeritus at the Limoges University, it attracted comments and amendments from around forty legal experts from twenty-two different countries in the context of a non-governmental organisation created by Michel Prieur, the International Center of Comparative Environmental Law. ${ }^{18}$ Its designers thought that there was room then for a third Covenant, codifying environmental rights, supplementing the Covenant on Economic, Social and Cultural Rights and Covenant on Civil and Political Rights of $1966 .{ }^{19}$ Even though its object was slightly different, it was a project somewhat in competition with the Pact, more or less contemporaneous and because it also came from a (different) group of French lawyers. It did not receive the same support from French authorities, as they feared that in the current international context, its human-rights approach risked crippling it.

The idea of a Global Pact for the environment was born in 2015. During the twenty-first Conference of the Parties to the United Nations Framework Convention on Climate Change ('COP 21'), a French think tank comprised of law practitioners and professors, the Club des Juristes, published a report entitled Renforcer l'efficacité $d u$ droit international de l'environnement - Devoirs des États, droits des individus. ${ }^{20}$ This report recommended, among a series of proposals, the adoption of a universal environmental charter, in the form of a legally binding international convention. ${ }^{21}$ For the authors of this report, it was time to lay down the fundamental principles of international environmental law in a legally binding instrument, universal in scope, so as to allow for the established principles to be relied upon in courts. ${ }^{22}$ From press conferences to conferences, in the written and oral press, the report of the Club des juristes was widely disseminated. Its authors successfully convinced the president of the French Constitutional Council, Laurent Fabius, of the merits of this project; he saw therein a natural extension of the French diplomatic action during the COP 21, over which he presided. Laurent Fabius endorsed this idea and encouraged the Environmental commission of the Club des juristes to start working on a draft treaty. In his view, the adoption in September 2015 of the Sustainable Development Goals (SDGs) by the General Assembly of the United Nations Organisation and in December 2015 of the Paris Agreement on climate change by the COP 21 had created a momentum capable of generating support for such a project. ${ }^{23}$

\section{The design of the draft Global Pact for the Environment}

\footnotetext{
${ }^{15}$ Ibid.

${ }^{16}$ World Commission on Environment and Development, Our common future (UNEP 1987) 276.

${ }^{17}$ Voir IUCN, Draft International Covenant on Environment and Development, op. cit.

${ }^{18}$ M. Prieur, J. Bétaille, M.-A. Cohendet, H. Delzangles, J. Makowiak, P. Steichen, 'Projet de Pacte international relatif au droit des êtres humains à l'environnement', Revue juridique de l'environnement (2017) vol.42, n², 380-397.

${ }^{19}$ International Covenant on Economic, Social and Cultural Rights of 16 December 1966 (entry into force 3 January 1976); International Covenant on Civil and Political Rights of 16 December 1966 (entry into Force: 23 March 1976).

${ }^{20}$ Commission environnement, Club des juristes, Renforcer l'efficacité du droit international de l'environnementDevoirs des États, droits des individus (Club des juristes, November 2015) 123, <http://www.leclubdesjuristes.com/wpcontent/uploads/2015/11/CDJRapportsRenforcer-lefficacitéNov.2015FR.pdf> last accessed on 14 February 2020.

${ }^{21}$ Ibid., p. 106.

${ }^{22}$ Ibid., p. 104

${ }^{23}$ United Nations General Assembly, Resolution A/RES/70/1 of 25 September 2015, Transforming our world: the 2030 Agenda for Sustainable Development; Paris Agreement of 12 December 2015, UNTC, Chapter XXVII.
} 
After recalling the drafting process, we will present the form and structure, and then the content of the Pact, hesitating between great caution and a touch of audacity.

\subsection{The drafting process}

The work of the drafting of the Global Pact began in the fall of 2016, under the leadership of Yann Aguila, a former senior member of the French Council of State and now a lawyer. The goal was first to codify the fundamental principles of international environmental law into one single legally binding instrument. However, in terms of method, the work was more akin to that of learned societies such as the Institute of International Law or the International Law Association, than to that of the International Law Commission. ${ }^{24}$ For practical reasons, due to time constraints and to their profiles (mainly French law specialists), the persons involved paid little attention to existing practice - and in particular to national practice dealing with international environmental law issues - but drew heavily on major international declarations, on the basis that they reflected global consensus. These experts drew inspiration in particular from the Stockholm Declaration of 16 June 1972, the World Charter for Nature of 28 October 1982, the Rio Declaration of 14 June 1992 and the RIO+20 Declaration The future we want of 22 June 2012. ${ }^{25}$ The experts did, however, conduct, albeit in a more general way, a study of a number of national laws, in particular constitutional laws, where French law and the French Charter for the environment played a big part. The recommendation given by Laurent Fabius to the writers was to take a pragmatic approach, so that the project wouldn't get shelved like previous ones. Naturally, this led to the choosing of cautious, 'open texture' formulations, and to limiting the part of gradual development.

Aware of the need to internationalise the project in order to increase the international legitimacy of the Pact and to have greater input from a larger variety of domestic legal systems and developments, the French writers decided to involve a group of about 100 foreign experts, environmental law specialists representing forty nationalities. The group was consulted on five occasions through a series of written questionnaires regarding:

- the general presentation of the project and open-ended questions,

- the architecture of the Pact and the drafting approach,

- the monitoring mechanisms,

- the wording and content of the principles,

- the preparation of a White Paper presenting and commenting the draft Pact.

The interactions between the French drafters and international experts led to a first draft, finalised during a working day organised at the Constitutional Council, bringing together the French drafters and a number of international experts invited for the occasion, approximately forty experts constituting the GEP (Group of Experts for the Pact), actively chaired by Laurent Fabius. On the next day, almost 25 years to the day after the adoption of the Rio Declaration, on 24 June 2017, the project was officially presented during a conference organised at the Sorbonne and attended by various personalities, such as Ban Ki Moon, former UN SecretaryGeneral, former governor of California Arnold Schwarzenegger, Mary Robinson, Laurence Tubiana and climatologist Jean Jouzel. Delivering the closing speech, just a few days after launching his 'Make our planet great again' operation, ${ }^{26}$ French President Emmanuel Macron promised to defend the project before the UN without delay.

\subsection{The form and structure}

As adopted following the conference at the Sorbonne, the draft Pact was in the form of a complete and ready-to-be-adopted draft treaty. In the words of Michel Virally, its supporters

\footnotetext{
${ }^{24}$ Y. Kerbrat, 'Le Pacte mondial pour l'environnement: vers une nouvelle codification?', Communication at the Second World Meeting of Societies for International Law, Current challenges to international law. The role of societies of international law, The Hague, 2-3 September 2019.

25 UNO, The United Nations Conference on Sustainable Development: Rio+20, The future we want, A/CONF.216/L.1*, 19 June 2012.

${ }^{26}$ White Paper on the Global Pact for the Environment (Le Club des juristes 2017) 3.
} 
viewed it as a code in the technical sense of the word, i.e. a single document that brings together all the principles and all the rules found in dispersed legal instruments and in very many international resolutions. ${ }^{27}$ The project constituted the first step - doctrinal, as not yet discussed and modified by States - of a codification exercise.

In terms of structure, the draft project included a preamble, followed by twenty-six articles: twenty principles and six articles for the final provisions. The two core principles of the project were set out in articles 1 and 2, and echoed principles 1 and 2 of the French Charter for the environment. ${ }^{28}$ The 'Right to an ecologically sound environment' (article 1), was thus paired with the 'Duty to take care of the environment' (article 2). The draft Pact then focused on substantial obligations (adequate prevention of environmental damages, precautionary principle, integration and sustainable development) as well as procedural obligations (access to information, public participation, access to environmental justice). Some provisions dealt with State cooperation, but most of them were mostly aimed at 'internal consumption', ${ }^{29}$ namely at inspiring national laws. The draft also provided for a monitoring mechanism, directly derived from the Paris Agreement on climate, ${ }^{30}$ relying on the creation of a compliance committee 'to facilitate implementation of, and to promote compliance with', the Pact (article 21).

\subsection{The content of the project - great caution and a touch of audacity}

In line with the writers' pragmatic approach, the formulations were for the most part very cautious. According to Laurent Fabius, the writers had tried to ensure that the text should be "votable' ${ }^{31}$ and most of the principles set out in the draft were already the object of a consensus in international environmental law. ${ }^{32}$ The writers even used some formulations directly from the Rio Declaration, without necessarily taking into account how far the Rio principles had come in twenty-five years, both within international law and in domestic laws. ${ }^{33}$ This is true for example of the principle of prevention of damage to the environment (article 5). The chosen wording was that of the Rio Declaration and other instruments adopted at the same time: 'The Parties have the duty to ensure that activities under their jurisdiction or control do not cause damage to the environments of other Parties or in areas beyond the limits of their national jurisdiction'. The project could have built upon the international case law that has emerged since 1992, which has specified the content and scope of this duty, now viewed as a positive obligation to take all possible, reasonable or appropriate measures to prevent transboundary environmental damage. ${ }^{34}$ The draft Pact required of the Parties the preparation of an environmental impact assessment, without giving States further guidance on the preparation of such assessment. Yet the preparation of an impact assessment, in the context of a risk of transboundary damage, is a customary obligation. The International Court of Justice has found, in the case regarding pulp mills, that there is in this matter 'a practice, which in recent years has gained so much acceptance among States that it may now be considered a requirement under general international law to undertake an environmental impact assessment where there is a risk that the proposed industrial activity may have a significant adverse impact in a

${ }^{27}$ M. Virally, 'La Charte des droits et devoirs économiques des États, Notes de lecture' (1974) Annuaire français de droit international, 31

${ }^{28}$ According to the first article of the French Charter, 'Chacun a le droit de vivre dans un environnement équilibré et respectueux de la santé'. According to its article 2, 'Toute personne a le devoir de prendre part à la préservation et à l'amélioration de l'environnement'.

${ }^{29}$ S. Laghmani, 'Droit international et droits internes : vers un renouveau du jus gentium ?', in R. Ben Achour, S. Laghmani (eds), Droit international et droits internes. Développements récents (Pedone 1999) 34.

${ }^{30}$ Paris Agreement of 12 December 2015; Decision 20/CMA.1 (2018), Modalities and procedures for the effective operation of the committee to facilitate implementation and promote compliance referred to in Article 15, paragraph 2, of the Paris Agreement, paras 32 et seq.

${ }^{31}$ Interview of L. Fabius, 'Le droit est essentiel pour s'adapter au monde nouveau et pour adapter ce monde nouveau. C'est le but du Pacte mondial pour l'environnement', La semaine juridique (2017) n²8, 1354.

${ }^{32}$ White Paper on the Global Pact for the Environment (Le Club des juristes 2017), 3.

${ }^{33}$ See for instance article 5 on prevention, article 6 on precaution or even article 18 on cooperation.

${ }^{34}$ Y. Kerbrat, S. Maljean-Dubois, 'La contribution en demie teinte de la CIJ au droit international de l'environnement dans les affaires Costa-Rica - Nicaragua', Journal du droit international (2018) 1133-1154. 
transboundary context, in particular, on a shared resource'. ${ }^{35}$ However, for the Court, 'it is for each State to determine in its domestic legislation or in the authorization process for the project, the specific content of the environmental impact assessment required in each case, having regard to the nature and magnitude of the proposed development and its likely adverse impact on the environment as well as to the need to exercise due diligence in conducting such an assessment' ${ }^{36}$ Thus it was more on the content and modalities of the principle that the draft Pact could have had an added-value by supplementing customary law, rather than on the principle itself. Here, the drafters stuck to a strict codification, and did not go to the progressive development way. It should be added that the project laid down the obligation to carry out impact assessments in the context of the prevention of transboundary harm, giving the impression that such an obligation would only apply in a transboundary context. This was precisely an issue on which a gradual development of international law was also expected. The writers could have relied here on the fact that national laws massively provide for the preparation of impact assessments, outside of any risk of transboundary harm. In the same way, article 7 states that "... Parties shall immediately notify other States of any natural disasters or other emergencies that are likely to produce sudden harmful effects on the environment of those States. Parties shall promptly cooperate to help concerned States". Again, it has a low valueadded, largely relying on past instruments, as in the Rio Declaration and in treaties dealing with technological disasters. ${ }^{37}$

A route that was not explored would have been for the Pact to be presented as a framework convention, designed to be completed going forward by protocols, one of which could have dealt with impact assessments. As the project did not provide for the establishment of a Conference of the Parties, it also could not have been completed going forward by a set of decisions interpreting it, clarifying it and developing it. ${ }^{38}$ Yet, this institutionalisation is one of the key elements in the implementation of environmental agreements. ${ }^{39}$ It seems to be necessary, in fact, if only to allow for the established compliance committee to work. ${ }^{40}$

Moreover, apart from a reference in the preamble to the rights and knowledge of indigenous populations, of local communities, there was nothing in the draft about indigenous people and traditional knowledge, despite the international law developments that have taken place since 1992.

Some innovative provisions were introduced by the project, such as the non-regression principle. Promoted in particular by Michel Prieur, the non-regression principle exists, for example, in French law in article L 110-1 of the Environmental code laying down that:

'Le principe de non-régression, selon lequel la protection de l'environnement, assurée par les dispositions législatives et réglementaires relatives à l'environnement, ne peut faire l'objet que d'une amélioration constante, compte tenu des connaissances scientifiques et techniques du moment'. ${ }^{41}$

83.

${ }^{35}$ Judgment of 20 April 2010, Pulp Mills on the River Uruguay (Argentina v. Uruguay), Judgment, I.C.J. Reports 2010,

${ }^{36}$ Ibid. It is recalled by Certain Activities Carried Out by Nicaragua in the Border Area (Costa Rica v. Nicaragua) and Construction of a Road in Costa Rica along the San Juan River (Nicaragua v. Costa Rica), Judgment, I.C.J. Reports 2015, p. 665 .

${ }^{37}$ See also Draft articles on the protection of persons in the event of disasters 2016, adopted by the International Law Commission at its sixty-eighth session, in 2016, and submitted to the General Assembly as a part of the Commission's report covering the work of that session (A/71/10), para. 48.

${ }^{38}$ In the same vein, N. Ait-Aissi Paillon, 'Pacte mondial pour l'environnement : un appui à la gouvernance mondiale de l'environnement ?', (2018) Cahiers du CERIUM, Montréal, Working Paper n¹2, 29.

${ }^{39}$ P. Sand, The Effectiveness of International Environmental Law. A Survey of Existing Legal Instruments (Grotius Publications 1992) 539.

${ }^{40}$ G. de Lassus Saint-Geniès, 'Not All that Glitters Is Gold. An Analysis of the Global Pact for the Environment Project' (2019), CIGI Papers No. 215, 4.

${ }^{41}$ See M. Prieur, G. Sozzo (eds), La non-régression en droit de l'environnement (Bruylant 2012). 
The wording of the draft Pact, according to which 'The Parties and their sub-national entities refrain from allowing activities or adopting norms that have the effect of reducing the global level of environmental protection guaranteed by current law' was, however, much weaker. The project also featured a provision on resilience, innovative by its general formulation and because it associated biodiversity and human communities: 'The Parties shall take necessary measures to maintain and restore the diversity and capacity of ecosystems and human communities to withstand environmental disruptions and degradation and to recover and adapt'. ${ }^{42}$ However, other innovative principles were not included, such as the in dubio pro natura principle, the need to protect the integrity of the Earth's ecosystem, the need to protect environmental activists or the advancement of the rights of nature. ${ }^{43}$

Another interesting and innovative aspect of the preliminary draft was the role it assigned to private actors. Alongside obligations traditionally aimed at States, the draft conferred rights and obligations on private persons. The text praised, in the preamble, 'the vital role of nonState actors, including civil society, economic actors, cities, regions and other subnational authorities in the protection of the environment'. By creating rights on the part of private persons, it created primary rights, but also a 'secondary' right to bring a claim for damages in the event of a violation of those primary rights. And the project went further than other international instruments on the environment, in particular the Paris Agreement, ${ }^{44}$ as the idea was also to impose obligations on non-State actors, and finally to encourage the materialization of these rights and obligations by States.

In terms of rights, the project conferred on 'Every person' 'the right to live in an ecologically sound environment adequate for their health, well-being, dignity, culture and fulfilment' ${ }^{45}$ While 155 States recognise a right to a healthy environment in their constitution or fundamental law, ${ }^{46}$ there is no treaty of universal scope laying down such a right in such a general manner. Its position as the first principle of the Pact showed the importance placed on it as 'a potential Grundnorm of the Pact itself and possibly of global environmental law and governance'. ${ }^{47}$ The potentialities of the provision, in particular in terms of litigation, were huge, especially as it was supplemented by a procedural section with the recognition of a right to access information on the environment, ${ }^{48}$ to public participation ${ }^{49}$ and to access justice. ${ }^{50}$ While France, in particular through its constitutional Charter for the environment, already guarantees some of these rights, these provisions could benefit a great number of private actors in courts that are still overcautious in this respect, and encourage for example better access to the courts for NGOs turning to justice to improve environmental protection. This, even though '[e]xplicit recognition of the human right to a healthy environment thus turned out to be unnecessary for the application of human rights norms to environmental issues'. ${ }^{51}$ The Aarhus Convention on access to information, public participation in decision-making and access to justice in environmental issues of 25 June 1998 has paved the way on this issue. Adopted in the context of the United Nations Economic Commission for Europe, the Convention is open for accession by any Member state of the UN and the Conference of the Parties has encouraged this extension

\footnotetext{
42 Article 16.

${ }^{43}$ L. J Kotzé, D. French, 'A critique of the Global Pact for the Environment: A stillborn initiative or the foundation for Lex Anthropocenae?' (2018) 18:6 Intl Envtl Agreements: Politics, L \& Economics 1, 829.

${ }^{44}$ H. Van Hasselt, 'The Role of Non-State Actors in Reviewing Ambition, Implementation, and Compliance under the Paris Agreement' (2016) Climate Law, Volume 6: Issue 1-2, 91-108.

${ }^{45}$ Article $1^{\text {er. }}$.

${ }^{46}$ David R. Boyd, 'Catalyst for change: evaluating forty years of experience in implementing the right to a healthy environment', in John H. Knox and Ramin Pejan (eds) The Human Right to a Healthy Environment (Cambridge University Press 2018) 17-42.

${ }^{47}$ L. J Kotzé, D. French, 'A critique of the Global Pact for the Environment: A stillborn initiative or the foundation for Lex Anthropocenae?’ (2018) 18:6 Intl Envtl Agreements: Politics, L \& Economics 1, 823.

${ }^{48}$ Article 9.

${ }^{49}$ Article 10.

${ }^{50}$ Article 11.

${ }^{51}$ Report of the Special Rapporteur on the issue of human rights obligations relating to the enjoyment of a safe, clean, healthy and sustainable environment, Note by the secretariat, 24 January 2018, A/HRC/37/59, para 13.
} 
beyond the scope of the Commission on several occasions, ${ }^{52}$ albeit unsuccessfully up until now. It is true that this is a demanding and relatively intrusive convention, with an unusual compliance review process. The Convention now has an equivalent on the American continent, with the Regional Agreement on Access to Information, Public Participation and Justice in Environmental Matters in Latin America and the Caribbean of 4 March 2018, which even more prominently endorses the right to a healthy environment. ${ }^{53}$

A universalization of these instruments, or at least of their underlying principles, has been expressly called for by the Special Rapporteur on the issue of human rights obligations relating to the enjoyment of a safe, clean, healthy and sustainable environment. ${ }^{54}$ For John Knox:

'The infusion of human rights norms into international environmental law can help to reenergize the field, by making clear that environmental protection is vital to human wellbeing, dignity, equality and freedom; by supplying standards, including for rights to information, public participation and access to justice, that are vital to inclusive and robust environmental policymaking; and by opening new avenues for individuals and communities to seek effective remedies for environmental harm'. ${ }^{55}$

John Knox however pointed out that there is an ongoing momentum and that it will continue with or without the Pact. ${ }^{56}$

As for duties, although only one was formally expressed as such, it had the merit of being very general with regard to its recipients and to its objective, both preventive and curative:

Every State or international institution, every person, natural or legal, public or private, has the duty to take care of the environment. To this end, everyone contributes at their own levels to the conservation, protection and restoration of the integrity of the Earth's ecosystem'. 57

While certain soft law international instruments such as the OECD Guidelines for multinational enterprises ${ }^{58}$, the Global compact $^{59}$ or the United Nations Guiding Principles on Business and Human Rights ${ }^{60}$ already include provisions to that effect, here as well, there is no treaty laying down such a duty, such an obligation even, in a legally binding instrument. It should also be pointed out that behind many other provisions of the Pact that were voluntarily left without a subject, expressed in a passive form, there were provisions that targeted everyone, and thus also private persons. The project entailed, for the future, rights and duties in equal measure. Thus, '[i]ntergenerational equity shall guide decisions that may have an impact on the environment'; 61 'The necessary measures shall be taken to prevent environmental harm'. ${ }^{62}$ This was also the case for article 6 on the precautionary principle or article 7 on the adequate environmental damages.

52 According to its article $19 \S 3$, 'Any other State, not referred to in paragraph 2 above, that is a Member of the United Nations may accede to the Convention upon approval by the Meeting of the Parties'. See also ECE/MP.PP/2011/2/Add.1 (Decision IV/5 of the Conference of the Parties).

${ }^{53}$ This Accord is not yet into force. It has received only 5 ratifications on the 11 needed.

${ }^{54}$ Report of the Special Rapporteur on the issue of human rights obligations relating to the enjoyment of a safe, clean, healthy and sustainable environment, op. cit.

55 J.H. Knox, 'The Global Pact for the Environment: At the crossroads of human rights and the Environment' (2019) RECIEL, 2019, vol. 28, 47.

${ }^{56}$ Ibid.

${ }^{57}$ Article 2.

${ }^{58}$ OECD, 2011 Update Of The OECD Guidelines For Multinational Enterprises (OECD 2011).

${ }^{59} \mathrm{Global}$ Compact, The ten principles, UN, $<$ https://www.unglobalcompact.org/what-is-gc/mission/principles $>$ last accessed on 14 February 2020.

60 UNO, Guiding Principles on Business and Human Rights, HR/PUB/11/4, 2011,

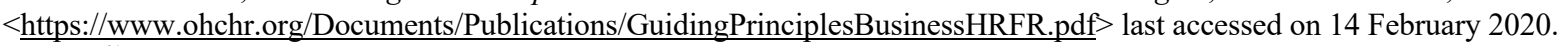

${ }^{61}$ Article $4 \S 1$.

${ }^{62}$ Article $5 \S 1$. 
It should of course be emphasized that there is no presumption of direct applicability for international norms in national legal systems. ${ }^{63}$ Given their formulation, it is not clear that these various provisions could have created within national regimes, a direct effect, a horizontal effect (applying to relations between individuals) or even a vertical one (between individuals and the State). In any case however, as highlighted by Evelyne Lagrange, a State that enters into an international obligation must fulfil it and, if its internal legal order does not provide for the application of the international norm as it stands, it must make the necessary changes to its legislation to ensure the fulfilment of the obligations undertaken. In 1925, the Permanent Court of International Justice pointed out that this was a 'principle which is self-evident' ${ }^{64}$ At the same time, all domestic legal orders do not show the same level of openness and the diligence required from a State is practically never limited to the adoption of primary domestic norms literally in line with the primary international norms. ${ }^{65}$ But national climate-related litigation proceedings, which are multiplying across the globe, are a good laboratory to experiment and change the relations between domestic laws and international law from this point of view, whether through the direct or indirect application of international law within internal legal regimes or by an interpretation thereof in line with international law. The explosion of climaterelated lawsuits leads to the development of reflexes on the part of claimants in terms of relying on international law, including customary international law. ${ }^{66}$

Lastly, dedicating one provision to the 'role of non-State actors and subnational entities', the Pact specified that:

'The Parties shall take the necessary measures to encourage the implementation of this Pact by non-State actors and subnational entities, including civil society, economic actors, cities and regions taking into account their vital role in the protection of the environment'. ${ }^{67}$

While this provision was in keeping with the innovative provisions in the preamble of the Paris Agreement and the content of the Paris COP decision adopting the latter, ${ }^{68}$ that encouraged non-State actors to get involved in the fight against climate change, it went one step further. The Pact encouraged Parties to adopt concrete measures: the encouragement should not be ignored, it should also benefit from the States' impetus. The realization - late but welcome - of the fact that the involvement of all actors (in particular private ones) is necessary, was clearly at work. The Pact acknowledged the need to rely on their action to reinforce the effectiveness of international environmental law.

All these provisions, read together, would truly constitute a small revolution with regard to the recognition of the role, rights and obligations of private actors. From 'virtual subjects' to vigilant actors, ${ }^{69}$ it was understandable that businesses should be very interested in this project, which lied at the crossroads of international environmental law and of international human rights law. More than an opportunity - encouraging the harmonisation of national laws and thus increasing legal security - businesses were more likely to view it as a legal risk and to express their resistance to such duties, openly or in a more discreet manner. ${ }^{70}$ The potential impact of

\footnotetext{
${ }^{63}$ E. Lagrange, 'L'efficacité des normes internationales concernant la situation des personnes privées dans les ordres juridiques internes' (2012) RCADI, vol. 356, 332.

${ }^{64}$ Ibid., 337. PCIJ, February 21st, 1925, Collection of Advisory Opinions, Series B N 10 , Exchange of Greek and Turkish Populations, 20.

${ }^{65}$ Ibid., 337.

${ }^{66}$ L. Wegener, 'Can the Paris Agreement Help Climate Change Litigation and Vice Versa?', Transnational Environmental Law (2020) 1; C. Cournil, L. Varison (eds), Les procès climatiques. Entre le national et l'international (Pedone 2018) 298.

${ }^{67}$ Article 14.

${ }^{68}$ See Paris Agreement, Dec. 12, 2015, 55 I.L.M. 743 (2016); U.N.F.C.C.C. Dec. 2/CP.19, Nov. 23, 2013, U.N. Doc. FCCC/CP/2013/10/Add.1 (2014), §116-123.

${ }^{69}$ P. Thieffry, 'Pacte mondial pour l'environnement - Le rôle du secteur privé dans le Pacte mondial pour l'environnement', Journal du droit international (2019) n 3, 739-754.

${ }^{70}$ Ibid.
} 
such a treaty on national laws, and even on European law, was likely to be significant, no matter what the promoters of the Pact said. ${ }^{71}$

On the other hand, the compliance process provided for was rather traditional, at the international level, and very mindful of State sovereignty. It was inspired more by international environmental law than by international human rights law, and was not at the junction of both like some existing mechanisms are. ${ }^{72}$ As it was designed, it was not possible for private actors to trigger this process. There was also no risk for them to be brought before a court or even a non-litigious monitoring body. This was a direct consequence of the realistic approach of the Pact's drafters, bearing in mind that as a rule, the bolder the substantial provisions, the less States are inclined to set up an intrusive, and potentially punitive, compliance mechanism.

Thus, out of concern for realism, the draft Project hesitated between great caution and a touch of audacity. One can of course criticise the balance adopted by the writers between codification and gradual development, finding the project overly cautious. The idea for its writers was to be able to convince the parties involved to launch negotiations, but it was also designed as a 'draft zero', to serve as a basis for negotiation. However, both goals are incompatible and this is perhaps what explains, in part at least, the failure of the draft Pact. To convince the parties involved to launch negotiations, best to have a cautious text, which one can say will not change much in practice, as it simply lays down principles that have already been acknowledged. As a 'draft zero', however, it is best to present a very ambitious text, at least from the point of view of environmental activists, as it is bound to be trimmed down and weakened. By pursuing both objectives, the writers were ultimately taking the risk of failing to attract both activists and reluctant parties. Not to mention the fact that the very idea of a codification of main principles of environmental law had been criticised, from the beginning, given the risks it inherently carries. The criticisms were no more and no less than the usual criticisms of any codification process. As pointed out by Yves Daudet and Anne-Thida Norodom, the primary criticism consists in highlighting that 'codification leads to a sclerosis of the law, compared to customary law which adapts, slowly, to realities and to needs, from which it is directly derived. And the advantages found in the greater certainty and precision of a written instrument compared to customary law can be annihilated by the risk of a 'double standard' ${ }^{13}$ that consists in submitting the same subject to different rules. This situation can actually happen if the codification only partially achieves its goal for lack of a significant number of ratifications of the convention. In that case, an element of uncertainty may arise, since it will be considered that there are significant differences between the customary rule and the conventional rule. The uncertainties thus created around customary law, more serious than before its codification, lead Roberto Ago to recommend that overly radical codification initiatives should be abandoned where they would have no real chance of success' ${ }^{74}$

From this point of view, the welcome received by the project from the doctrine was varied, some viewing it as a very good idea, 'the type of innovative, big thinking necessary to reverse course on environmental degradation', ${ }^{75}$ others as a promising way of 'defragging' international environmental law, ${ }^{76}$ and others, as a unimaginative initiative which, by its title (Global Pact for the Environment) and the principles set out therein, reflected a dated approach regarding these issues, failing to take into account the recent knowledge on the Anthropocene,

\footnotetext{
${ }^{71}$ On the consequences on European law, see P. Thieffry, 'The proposed Global Pact for the Environment and European Law', European Energy and Environmental Law Review, October 2018, 182.

${ }^{72}$ As the Aarhus Convention Compliance Committee. See V. Koester, 'Le comité d'examen du respect des dispositions de la convention d'Aarhus: Un panorama des procédures et de la jurisprudence', Revue européenne du droit de l'environnement (2007) No. 3, 251-276.

${ }^{73}$ Quoting K. Zemanek, 'Codification of international law, salvation or dead end?', Mélanges Ago (Milan 1987), vol. I, 589.

${ }^{74}$ Our translation, Y. Daudet, A.-T. Norodom, 'La coutume. Codification', Jurisclasseur Droit international, Lexis Nexis, fascicule 75, August 2014. Quoting R. Ago, 'Nouvelles réflexions sur la codification du droit international' (1988) $R G D I P$, 573. See also Ch. de Visscher, 'La codification du droit international' (1924) RCADI, t. 6, 386-407.

${ }^{75}$ T. Parejo Navajas, N. Lobel, 'Framing the Global Pact for the Environment: Why It's Needed, What It Does, and How It Does It', Fordham Envtl L Rev (2018) vol. $30 \mathrm{n}^{\circ} 1,61$.

${ }^{76}$ M. Young, 'Global Pact for the Environment: Defragging international law?', EJIL: Talk!, August 29 (2018).
} 
the way the planetary system works and planetary boundaries, and which would be, as a legally binding instrument, 'inalienably regressive'.$^{77}$

In any event, the codification exercise is likely to remain unfinished, in view of the reactions of States to the draft Pact.

\section{Life and death of the Global Pact for the Environment}

Promoters of the Pact convinced the General Assembly to initiate a process that could have led to the official launch of negotiations, but this was not the path States decided to take. This section traces the life, and death, of the Pact within UN bodies, and looks at its future prospects.

\subsection{The Pact before the UN General Assembly}

After being presented at the Sorbonne conference, in late June 2017, the project was promoted during the summer by French diplomacy at various bilateral meetings with States identified as key to the process, such as China or India. On 19 September 2017, the French organised a side event to the United Nations General Assembly to present the project and show the support it had received, in the presence of around twenty chiefs of State or government. Approximately fifty States approved of the Pact, among which States as varied as Bolivia, China, Egypt, Fiji, Gabon, India, Mali or Poland. They convinced France to officially launch its project. ${ }^{78}$ But afterwards, the resistance to overcome turned out to be much stronger than anticipated by the promoters of the Pact. It took several more months of discussions for the UN General Assembly (UNGA) to make a decision in its resolution 72/277, adopted on 10 May 2018 and entitled rather ambiguously 'Towards a Global Pact for the Environment'.

Presented by France, the resolution was sponsored by 71 delegations. Despite its title, this resolution did not in any way launch negotiations towards a Global Pact for the Environment. It entrusted the UN Secretary-General (UNSG) with the task of submitting to the UNGA a 'technical and evidence-based report that identifies and assesses possible gaps in international environmental law and environment-related instruments with a view to strengthening their implementation'. The UNGA also decided to establish an ad hoc open-ended working group (AHOEWG), open to Member States, members of specialised institutions and NGOs having consultative status with the ECOSOC. This group was instructed, in light of the UNSG report, to 'discuss possible options to address possible gaps in international environmental law and environment-related instruments, as appropriate, and, if deemed necessary, the scope, parameters and feasibility of an international instrument, with a view to making recommendations, which may include the convening of an intergovernmental conference to adopt an international instrument, to the Assembly during the first half of 2019'.

The launch of negotiations therefore remained a possibility, albeit a narrow one. Despite its ambiguity, the resolution could not be adopted by consensus and had to be put to a vote. It received 143 votes in favour, 7 abstentions (Saudi Arabia, Belarus, Malaysia, Nicaragua, Nigeria and Tajikistan) and 6 votes against (United States, Philippines, Russia, Syria, Turkey), which did not bode well for the future.

\subsubsection{The report of the UN Secretary-General}

The report, for which the UN Secretary-General relied on a number of international experts, was submitted in December 2018. ${ }^{79}$ Designed to serve as a basis for the work of the Working Group, its very title revealed its stance. Where the UNGA asked for an analysis on

\footnotetext{
${ }^{77}$ L. J Kotzé, D. French, 'A critique of the Global Pact for the Environment: A stillborn initiative or the foundation for Lex Anthropocenae?’, op. cit., p. 820.

${ }^{78}$ S. Roger, 'Examen de passage réussi pour le Pacte mondial pour l'environnement', Le Monde (20 September 2017).

79 UNO, Report of the Secretary-General, Gaps in international environmental law and environment-related instruments: towards a global pact for the environment, A/73/419, 13 December 2018, $51 \mathrm{p}$.
} 
'possible gaps', the report was entitled 'Gaps in international environmental law and environment-related instruments: towards a global pact for the environment'.

The report did indeed conclude that there were many gaps and deficiencies, regarding the corpus of texts, international environmental governance, as well as the application of international environmental law. Largely confirming the position of the Pact's promoters, it found that what was missing was a 'single overarching normative framework that sets out what might be characterized as the rules and principles of general application in international environmental law even though such principles may help unify the current, sectoral, approach to international environmental law and help fill the gaps in the rules laid out in treaties'. According to the report, some principles of international environmental law still lack clarity and are not recognised as universally applicable. The report also insisted on the fragmentation of international environmental law, both 'piecemeal and reactive' and the need to improve the coherence and synergy between the policies conducted. This fragmented framework reflects a fragmented governance, composed of 'a heterogeneous set of actors' 'revealing important coherence and coordination challenges'. The application of international environmental law at the national level is "constrained in many countries by the lack of appropriate national legislation, financial resources, environmentally sound technologies and institutional capacities'. In summary, the report concluded that:

'International environmental law and its effective implementation could be strengthened through such actions as the clarification and reinforcement of principles of international environmental law. This could be done through a comprehensive and unifying international instrument that gathers all the principles of environmental law. There should also be more effective reporting, review and verification measures and robust compliance and enforcement procedures and mechanisms, ensuring that those States that require support have adequate resources to enable them to effectively implement their commitments, and the role of non-State actors should be enhanced at multiple levels' ${ }^{80}$

Thus, while highlighting that it would not address all the gaps and deficiencies identified, the report very clearly concluded that establishing a new treaty would be appropriate to clarify the principles of international environmental law and to make them unquestionably positive: 'A comprehensive and unifying international instrument clarifying all the principles of environmental law would contribute to making them more effective and strengthen their implementation' ${ }^{81}$ This report was widely criticised. The doctrine attacked its lack of rigor in the key definition of these 'gaps', ${ }^{82}$ as well as its lack of ambition and its timidity. ${ }^{83}$ It was also criticised by States that overwhelmingly took position within 'three camps: those who think there are no gaps; those who agree with gaps as identified in the UNSG's report, but who don't agree with how they are formulated; and those who say there are gaps, but not the ones in the UNSG's report'. ${ }^{84}$

\subsubsection{The work of the Working Group}

The Working Group held three sessions in January, March and May 2019. In parallel, France organised many bilateral consultations to promote the draft Pact, prompting some to say that there were two parallel paths, the 'in' one and the 'off' one.

This work gave rise to interesting discussions, reflecting major differences between States that did not all share the same diagnostic, and that a fortiori did not agree on the policies to

${ }^{80}$ Ibid., $1-2$.

${ }^{81}$ Ibid., 7.

${ }^{82}$ C. Voigt, 'How a 'Global Pact for the Environment' could add value to international environmental law', RECIEL (2019) 16

${ }^{83}$ D. French, L. J. Kotzé, 'Towards a Global Pact for the Environment': International environmental law's factual, technical and (unmentionable) normative gaps', RECIEL (2019) 1-8.

${ }^{84}$ Summary of the First Substantive Session of the Ad Hoc Open Ended Working Group towards a Global Pact for the Environment, 14-18 January 2019, Earth Negotiations Bulletin (ENB), Volume 35 Number 1, 21 January 2019, 10. 
pursue or the measures to adopt. During the first meeting, for example, very lengthy discussions dealt with the very concept of a 'gap'. The U.S. and the CARICOM even requested at the end of the meeting that the co-chairs produce a document laying out the definition of gaps. ${ }^{85}$ Although many States did acknowledge the need to reinforce the implementation of international environmental law, however, despite the French efforts, support for the draft Pact - in particular in the form of a new treaty - was far from being unanimous. The European Union itself officially supported it, ${ }^{86}$ but rather weakly in practice; many countries of the EU are not in favour of a new treaty.

Between countries that found that the project could be counter-productive for environmental protection and those reluctant to make new commitments (the U.S., Brazil or Russia), the project failed to convince. The arguments of pro-environment players against the Pact were that, in a difficult context, where multilateralism is undermined, the launch of international negotiations towards a Pact for the environment could risk leading to a 'soft' text in terms of content. This would weaken environmental law and would freeze the formulation of principles when these derive their strength from their flexibility. The risk would not be worth it - what use would it be to codify the Rio principles when these are already largely disseminated within national laws and even in national constitutions?

In fact, courts often use international soft law whether at the national ${ }^{87}$ or international level. Indeed, international courts or arbitrators often rely on principles of international environmental law when determining the legal context of a dispute between States. In theory, for international principles to be part of the law applicable to a dispute brought before a court, they must be part of positive law: their nature as a custom or as a general principle of law must be recognised or they must be included in an international convention to which the States involved must be a party. But the reasoning of international courts is not always made clear from this point of view and it is probably so on purpose. ${ }^{88}$

There were also risks of contradiction, as pointed out already in the UN General Assembly resolution, which clearly stated that 'the process (...) should not undermine existing relevant legal instruments and frameworks and relevant global, regional and sectoral bodies' ${ }^{89}$ Indeed, the adoption of a Pact for the environment should not weaken pre-existing instruments, nor prevent States from adopting stronger commitments at a later stage. It could only be a minimum foundation. Yet, the draft Pact contained no provision to deal with the potential normative conflicts that the application of the lex posterior or lex specialis principles would not be able to prevent. If it doesn't modify existing treaties, how can it harmonise them and promote synergies? How could it positively influence the negotiation of future, more specific treaties?

To show some of the possible [ further ] complications, even at the WTO, the biotech jurisprudence means that, for the purpose of interpreting WTO law, based on the principle of systemic integration mentioned in article 31, paragraph 3(c) of the 1969 Vienna Convention on the law of treaties, an international treaty is only taken into account if it is applicable to all members of the WTO. ${ }^{90}$ The report of the Panel on biotech products was never rejected nor

\footnotetext{
${ }^{85}$ Ibid., 10

${ }^{86}$ Recommendation, Authorisation of the opening of negotiations on a Global Pact for the Environment, COM (2018) 138 final. Indeed, according to the recommendation for the Council decision, 'In order to protect the integrity of Union law and to ensure that the rules of international law and Union law on the protection of the environment remain consistent, it is necessary that the Union participates in the negotiations on the Pact'.

${ }^{87}$ G. de Lassus Saint-Geniès, 'Not All that Glitters Is Gold. An Analysis of the Global Pact for the Environment Project', op. cit., quoting the decision Spraytech v Hudson (2001), 16. One can mention the British Judgment Fishermen and Friends of the Sea (Appellant) $v$ The Minister of Planning, Housing and the Environment (Respondent) (Trinidad and Tobago) that is quoting the Pact project itself (Michaelmas Term [2017] UKPC 37 Privy Council Appeal No 0028 of 2016, 27 November 2010). However, one of the judges has been a member of the international Group of Experts for the Pact.

${ }^{88}$ See S. Maljean-Dubois, 'L'arrêt rendu par la Cour internationale de Justice le 25 septembre 1997 en l'affaire relative au projet Gabcikovo-Nagymaros (Hongrie / Slovaquie)', Annuaire français de droit international (1997), vol. XLIII, $286-332$.

${ }^{89}$ In its above-mentioned resolution of 10 May 2018.

${ }^{90}$ See Rapport du Groupe spécial, European Communities - Measures Affecting the Approval and Marketing of Biotech Products, WT/DS291/R, WT/DS292/R, WT/DS293/R, 29 September 2006. In the same vein, J. Pauwelyn, 'The Role of Public International Law in the WTO: How Far Can We Go?’, AJIL, 2001, p. 577 and Conflict of Norms in Public International Law,
} 
confirmed by the Appellate body. ${ }^{91}$ This requirement, which was not met in that instance and is only rarely met, means that article 31 , paragraph $3(\mathrm{c})$ essentially allows, in practice, for a convention-based rule to interact with a customary rule, but would not allow the interaction of a treaty such as the Pact with WTO law, although this is one of the key arguments of the Pact's supporters.

According to Japan and several other States, it still remained to be proved that a global instrument compiling principles could address the gaps and difficulties met in the implementation of international environmental law. ${ }^{92}$ The Pact would not solve the real problems encountered in the implementation of international environmental law : the lack of political will, the lack of means or inadequate governance. ${ }^{93}$ Ultimately, critics of the Pact saw in it a 'gadget' diverting attention, energy and means away from the implementation of the existing framework, composed, schematically, of a set of international conventions and of the Sustainable Development Goals adopted by the UNGA. Many delegations found that the Secretary-General's report had been biased and pointed out the hurry, even the amateurism or the arrogance, of French diplomacy in this matter. The French were accused of having tried to go around UN procedures and mechanisms by producing a 'version zero' outside of them. Armed with good intentions, they had tried to move fast where the UN process, structured by the practice of consensus, is a 'factory of slowness. ${ }^{94}$

Thus, France found itself rather isolated. After the three sessions, and even though the co-chairs attempted to recommend the launch of negotiations, ${ }^{95}$ the conclusions of the group did not support this recommendation. The discussions gradually undid most of the co-chairs' project. The Working group did however present thirteen substantial recommendations, and recommended that the UN General Assembly provide them to the UN Member States, to specialised agencies and to governing bodies of international conventions for their consideration and action 'as appropriate'. ${ }^{96}$ Officially burying the draft Pact, the General assembly subscribed to all the recommendations of the Working group at the end of August 2019. ${ }^{97}$

\subsubsection{Recommendations adopted by the General Assembly}

Many of the recommendations are reiterations (in particular of the Declaration The future we want) and/or are very general. Thus, the first recommendation (a) reaffirms the role of the UNEP, in a wording very close that the one set out in paragraph 88 of the Declaration The future we want, with an additional reference to the role of the United Nations Environment Assembly, which replaced, in 2014, the UNEP Governing Council and is based, contrary to the latter, on the principle of universal membership. The second recommendation (b) calls for renewed efforts at all levels to enhance the implementation of existing obligations and commitments under international environmental law, stressing the importance of enhanced ambition regarding means of implementation, including the provision and mobilization of all types and sources of means of implementation, consistent with the Addis Ababa Action Agenda

How WTO Law Relates to other Rules of International Law (CUP 2003) 257. See also Chile - Price Band System and Safeguard Measures Relating to Certain Agricultural Products, WT/DS207/R, 3 May 2002, 161.

${ }^{91}$ See European Communities and Certain Member States - Measures Affecting Trade in Large Civil Aircraft, Appellate Body Report, WT/DS316/AB/R, 18 May 2011, p 406. The Appellate Body encouraged caution in such a situation.

${ }^{92}$ Summary of the First Substantive Session of the Ad Hoc Open Ended Working Group towards a Global Pact for the Environment, 14-18 January 2019, Earth Negotiations Bulletin (ENB), Volume 35 Number 1, 21 January $2019,6$.

${ }^{93}$ S. Biniaz, '10 Questions to Ask About the Proposed 'Global Pact for the Environment', Columbia Law School, Sabin Center for Climate Change Law (August 2017) 9.

${ }^{94}$ Stefan C. Aykut, Amy Dahan, Gouverner le climat? Vingt ans de négociations internationales (Les Presses de Sciences Po 2015) 124 (our translation).

${ }^{95}$ Co-chairs non paper, Draft element of recommendations to the seventy-third of the General Assembly, 25 April 2019,

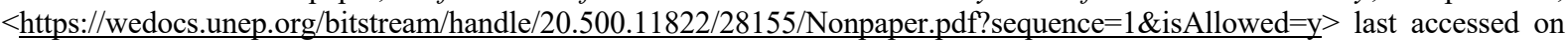
14 February 2020.

${ }^{96}$ See the document A/AC.289/6/Rev.1, Report of the ad hoc working group established pursuant to General Assembly resolution 72/277, 13 June 2019.

${ }^{97}$ See the above-mentioned General Assembly resolution 73/333, Follow-up to the report of the ad hoc open-ended working group established pursuant to General Assembly resolution 72/277, 30 August 2019. 
of the Third International Conference on Financing for Development and the 2030 Agenda for Sustainable Development. ${ }^{98}$ The eighth recommendation (h) encourages States that have not done so to consider ratifying multilateral environmental agreements and to effectively implement them. The ninth encourages States to strengthen, 'where needed', environmental laws, policies and regulatory frameworks at the national level, as well as capacities across all sectors for the effective implementation of international environmental law. The tenth recommendation (j) encourages States to mainstream environment into sectoral policies and programmes at all levels, including into national development and sustainable development plans. The eleventh recommendation $(\mathrm{k})$ promotes the active and meaningful engagement of all relevant stakeholders at all levels in the different forums related to the implementation of international environment law. The twelfth recommendation (l) encourages the implementation of the fifth Programme for the Development and Periodic Review of Environmental Law (Montevideo Programme V), adopted at the fourth session of the United Nations Environment Assembly on 15 March $2019\left(\mathrm{n}^{\circ} 4 / 20\right) .{ }^{99}$ The latter is very general.

With regard to international environmental governance, the Working group made various proposals that all point to the same direction, that of reinforced exchanges, collaboration and cooperation between international institutions, and support for the role of the UNEP in the matter. ${ }^{100}$ In fact, these recommendations are not really new. They simply invite States to further ongoing efforts. Indeed, after a lot of wishful thinking, cooperation has continuously increased over the past few years and it is beginning to bear fruit.

Given how general and how timid they are, and despite the support of the UN General Assembly, there is every reason to fear that these recommendations will not revolutionise international law, nor international environmental governance. The proposals of the Working group are essentially tantamount to encouraging developments that are already being promoted elsewhere, and are often already ongoing.

As for the draft Pact, the third recommendation (c), the wording of which was carefully negotiated, and at length, acknowledges 'the role of discussions on principles of international environmental law in enhancing the implementation of international environmental law, also noting the ongoing work in the International Law Commission on general principles of law'. This compromise wording satisfies those against the adoption of a new instrument, whether or not legally binding, laying down universal principles. Innocuous, it only recognises the role of discussions regarding the principles of international environmental law to reinforce its application, not the role of the principles themselves or the need to formulate, update, modernise them... It also notes the ongoing work of the International Law Commission on general principles of law. Indeed, the Commission has included on its agenda the question of 'general principles of law' and appointed a rapporteur who submitted, in April 2019, its first report. ${ }^{101}$

The idea is mainly for the Commission to be able to provide authoritative insights on the nature, scope and functions of the general principles of law and to specify the criteria and methods to be used to identify them. The Commission is seeking to identify general principles of law and in this respect, will contribute to an improved knowledge of the content and effect (legally binding or not) of these principles of international environmental law. However, the idea for now is that this will result in conclusions together with comments, not a draft treaty.

Many States specified during the discussions of the AHOEWG that it was best to await the result of this process before deciding or moving forward on environmental principles, but this could take many years. In reality, the work of the International Law Commission does not

98 Resolution A/RES/70/1 of 25 September 2015, Transforming our world: the 2030 Agenda for Sustainable Development.

${ }^{99}$ Final assessment of the Fourth Programme for the Development and Periodic Review of Environmental Law (Montevideo Programme IV) and proposals for a future programme, Report of the Executive Director, UNEP/EA.4/19, (UNEP 2018).

${ }^{100}$ See recommendations $\mathrm{d}, \mathrm{e}, \mathrm{f}, \mathrm{g}$ and $\mathrm{m}$.

${ }^{101}$ First report on general principles of law, Marcelo Vazquez-Bermudez, A/CN.4/732 (5 April 2019). 
prevent States from moving things along. Ultimately, the recommendation, by taking note of the ongoing work of the ICL, satisfies those States that do not wish to await their conclusion.

Without recommending, nor promoting such an approach, the acknowledgement of the role of discussions regarding principles of international environmental law to reinforce the implementation of international environmental law also leaves open the possibility of adopting a new legally or non-legally binding instrument laying down these principles. The discussions within the Working group and the wording chosen in the end do however tend to indicate that those in favour of a universal declaration of environmental principles, even if not legally binding, will find it extremely difficult to see their project through.

The weakness of these recommendations was foreseeable and had been pointed out as a risk by many delegations from the beginning of the process. ${ }^{102}$

\subsection{Future prospects}

On instruction of the UNGA, the recommendations must now be reviewed by the United Nations Environment Assembly, in order to prepare, for its fifth session in February 2021:

a political declaration for a United Nations high-level meeting, subject to voluntary funding, in the context of the commemoration of the creation of the United Nations Environment Programme by the United Nations Conference on the Human Environment, held in Stockholm from 5 to 16 June 1972, with a view to strengthening the implementation of international environmental law and international environmental governance, in line with paragraph 88 of the outcome document of the United Nations Conference on Sustainable Development, entitled 'The future we want'. ${ }^{103}$

In lieu of a treaty, the proposition stemming from the work of the Club des juristes could thus result in the adoption of a new international declaration. But here the chosen approach is still cautious. The AHOEWG has found a compromise approach as it intentionally refers, not to a declaration at the end of a large UN conference convened by the General Assembly, but to the preparation of a text by the United Nations Environment Assembly that would be a political declaration by a high-level UN meeting, in the context of the commemoration not of the Stockholm Conference itself, but of the creation of the UNEP during the Stockholm conference. The chosen approach reflects the desire not to raise such declaration to the same political level as those of Stockholm or Rio. Furthermore, the preparation will only take place in 2021 during the fifth United Nations Environment Assembly and nothing is planned until then.

The envisaged scenario thus seems to remove the prospect of a major declaration echoing previous 'grand' UN declarations adopted by large UN conferences. However, negotiated at the level of the UN, in the context of the United Nations Environment Assembly, within which all Member States are represented and to which many non-State players participate, adopted by consensus, the declaration could then be adopted by the UN General Assembly. The conclusions of the Working group do not provide therefor, but also do not prohibit it, although it must be said that to this day, there is no consensus on this point. It is clear that the conditions for the adoption of such a declaration will depend on its political weight and ultimately on its legal effect. At this stage, the conclusions of the Working group tend to point to a limited political weight.

A new declaration has at least two benefits compared to the treaty-based approach. Even if States do weigh each word in such an instrument, they are much less tense than when negotiating a treaty. The 'soft law' form could thus lead to a more precise and demanding content than a 'binding law' form. Furthermore, adopted by consensus, a declaration is of immediate effect on all UN member States, while a treaty must be ratified by States and can

\footnotetext{
${ }^{102}$ Summary of the Second Substantive Session of the Ad Hoc Open Ended Working Group towards a Global Pact for the Environment, 18-20 March 2019, Earth Negotiations Bulletin (ENB), Volume 35, Number 2, Friday, 22 March $2019,2$.

${ }^{103}$ See the above-mentioned General Assembly resolution 73/333, Follow-up to the report of the ad hoc open-ended working group established pursuant to General Assembly resolution 72/277, 30 August 2019.
} 
only be enforceable against those having ratified and only when they have done so. Ratification can take a long time, and it sometimes never actually takes place. A weakly ratified treaty can be counter-productive in relation to objectives of consolidation and of development of international environmental law. While it may not be very robust legally, as it is non-binding, a declaration can be politically far-reaching. As such, it can contribute to the revitalisation of the States' engagement in favour of the environment, and to giving new impetus to international cooperation. Even if soft law instruments are not, in theory, binding, they can have some form of legal value in practice: the care put into negotiating the content of such statements, and the fact that States sometimes accept the setting-up of a monitoring and compliance mechanism with regard to their application, ${ }^{104}$ are fairly reliable clues thereof. The degrees of normativity and effectiveness of soft law instruments are in fact variable. ${ }^{105}$

As for the objective pursued by such a declaration, for now, States are divided. For some, it would be the non-binding version (a prefiguration?) of the Global Pact for the environment, i.e. a declaration of universal principles on the environment equivalent to the Stockholm and Rio declarations. For the promoters of the Global Pact, this would be an acceptable way out, even though it is very far from their initial ambitions. However, in this scenario, the cautionary approach of the draft Pact, designed to become a treaty, could be a handicap by failing to instil the necessary ambition at the start of negotiations. A new declaration of principles would only be meaningful if it brought new elements compared to previous ones.

For many delegations, such an option is not desirable. There is no need to lay down once again general principles which, for the most part, already feature in many legally binding and non-legally binding instruments, at the international or national level. They lean more towards a strengthened implementation of the existing structure. Embarking on the negotiation of a new major declaration, equivalent to the Rio declaration, would be unwise in a difficult international context and could even lead to weaker formulations compared to those used in the Rio Declaration, and thus jeopardizing its legacy. For example, let us assume that the heart of the Declaration would be or should the recognition of a right to an ecologically sound environment and of principles of environmental democracy: access to information, public participation, access to justice, even the protection of environmental activists (which was not included in the draft Pact). These are very sensitive subjects and many States do not want new developments on these points. China, in particular, has drawn a red line on the non-insertion of provisions relating to human rights. ${ }^{106}$ As things currently stand, the declaration's possible content and goals still remain to be decided.

\section{Conclusion}

In the current context, States were not convinced by the French initiative for a new Global Pact for the Environment. Too short a timeframe, the need for a consensus within the Working group and the lack of support from major world powers: all of this most likely did not help French diplomats who had to battle against the headwinds. Opposition came from the usual suspects, but also from countries - or negotiators - that were truly willing to improve environmental protection but who were not persuaded that a new treaty would be the best way to achieve this. Given how it was received, the relevance of launching negotiations for a new declaration of universal principles is also unclear. The risk is that it would take a lot of time and effort, to the detriment of other, more pertinent action, with limited consequences or even

\footnotetext{
${ }^{104}$ See for instance the role of the former Commission on Sustainable Development in the monitoring of the implementation of the Agenda 21 or the one of the High-level Political Forum on Sustainable Development in the implementation of the Sustainable Development Goals.

${ }^{105}$ D. Shelton (ed), Commitment and Compliance. The Role of Non-binding Norms in the International Legal System (OUP 2000) 560 .

${ }^{106}$ E. Hege, D. Barbiche, 'Deuxième session de travail à Nairobi : un pas de plus vers un Pacte mondial pour l'environnement ?', Billet de blog (9 avril 2019) $<$ https://www.iddri.org/fr/publications-et-evenements/billet-de-

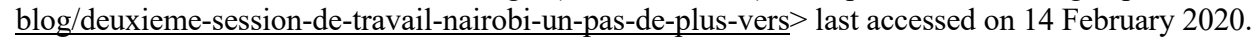


potentially negative effects, all the more so that the legitimacy and political reach of such a declaration could be weakened by the way it is adopted. In any case, the political context is not conducive to major breakthroughs. In these conditions, through their strategic choices, States must be careful not to weaken the existing framework and the action of treaty-based institutions.

Because of time constraints, discussions between States did not go as far as they could have gone. Even the report of the Secretary-general, which was meant to assess the situation and needs, was drafted too quickly, drawing criticism from States as being biased, incomplete and not sufficiently thorough. This was probably a missed opportunity, as an in-depth and consensus-based assessment of the situation is still the necessary prerequisite for progress. Such progress could take many forms other than the adoption of a Global Pact for the Environment and one can still hope that the entire process will not come to a halt, but will continue in the coming years and lead to concrete results. ${ }^{107}$

In this regard, our view is that States should focus primarily on three major issues in these early years of the twenty-first century. First, the coordination of international action. Environmental threats are complex and interact with one another; solutions cannot be found in isolated intervention. The interconnection of issues between climate, biodiversity, deforestation and acidification of oceans is particularly striking in this respect. From this point of view, concrete measures should be promoted, in order to decompartmentalise international governance, which is still mostly organised in silos despite recent progress. Second, the coordination of rules of international environmental law with the other principles and rules of international law. States must think of means to encourage a more balanced and 'systemic' interpretation of international law, for instance an interpretation of international trade law or of investment law, or of international human rights law, that better takes into account the principles laid down for environmental protection. They must stop undoing on the one side what they are doing on the other. Finally, the declaration could call for a reinforcement of the measures that support States in the national implementation of their international obligations, and in particular of international monitoring, but also of cooperation in all its forms, scientific, technical, or financial. In any case, it will remain difficult to make national egoisms give way, even in the face of the imperative to protect our biosphere and the community of living beings it represents.

\footnotetext{
${ }^{107}$ In the same vein, S. Biniaz, 'The UNGA Resolution on a 'Global Pact for the Environment': A chance to put the horse before the cart', RECIEL (2019), vol. 28, 33-39.
} 